\title{
The role of information infrastructure for climate change adaptation in the socio-ecological system of the Central Himalaya: availability, utility, and gaps
}

\author{
Praveen Kumar $^{1,2}$ (D) Rajiv Pandey $^{3} \cdot$ Christine Fürst $^{2} \cdot$ P. K. Joshi ${ }^{1,4}$
}

Received: 4 January 2021 / Accepted: 5 October 2021 / Published online: 26 November 2021

(c) The Author(s) 2021

\begin{abstract}
The present study intends to understand and disclose the role of information infrastructure in climate change adaptation and its underlying barriers in the communities of socio-ecological system (SES) in the Central Himalaya. The study makes use of primary data in its research methodology which comprises the use of questionnaires, oral interviews, and review of relevant literature. The data were collected using a questionnaire-based survey from 85 households in 11 villages. The study results show that road accessibility and irrigation facilities remarkably influence the educational, professional, and economic conditions of the communities. The research reveals how the flow of information through television, newspapers, village elders, and mobile phones influences perceptions of climate change in a different order. Information infrastructure availability is higher with the communities having access to the road network and irrigation facilities. The study concludes that in SES a good information infrastructure is highly relevant for reducing the current and future vulnerability of SESs to climate change. The study also provides recommendations for the dissemination of information on climate adaptation that suit the needs and demands of the Himalayan SESs and thus could help to close existing information gaps and barriers.
\end{abstract}

Keyword Adaptation $\cdot$ Coping strategy $\cdot$ Information barrier $\cdot$ Information infrastructure

\section{Climate change and socio-ecological systems of the mountains}

Climate change affects daily life and economic activities such as agriculture, impacting the livelihood of communities in their given social and ecological domains (WMO 2011, p.43; IPCC 2014). Therefore, climate data and knowledge from any reliable source are useful for local communities to take decisions on agricultural activities, natural resource

Praveen Kumar

pkb911@gmail.com

1 School of Environmental Sciences (SES), Jawaharlal Nehru University (JNU), New Delhi 110067, India

2 Department of Sustainable Landscape Development, Martin Luther University Halle-Wittenberg, 06120 Halle (Saale), Germany

3 Indian Council of Forestry Research and Education (ICFRE), Dehradun, India

4 Special Center for Disaster Research (SCDR), Jawaharlal Nehru University (JNU), New Delhi 110067, India management, preventing disease outbreaks, developing livelihoods, etc. (WMO 2011, p.26). Moreover, the consequence of climate change on socio-ecological systems (SESs) is being realized at the local level, leading to additional vulnerabilities, especially in food security, livelihood options, and risk and hazards (WMO 2011, p.26). Owing to a combination of factors such as awareness about climate, impacts of climate change, and other climate issues, the demand for climate information is increasing but at a moderate growth (WMO 2011, p.43). With such importance of climate-related information, World Metrological Organization (WMO) initiated the Global Framework for Climate Services (GFCS) to develop climate information services for all nations. The climate services aim to make provision by a generation of a wide range of information on past, present, and future climate for the facilitation of improved understanding of climate and its impacts on natural and human systems to equip policymakers for decision-making at all levels of society (WMO and GFCS 2016, p.10). Thus, the need for climaterelated information becomes quite essential for mountain communities due to their high degree of exposure to climate change. 
Mountains provide vital ecosystem services to the communities in the region as well as in plains (Joshi and Joshi 2019, p.785). These fragile ecosystems are exposed to multiple environmental stressors such as natural disasters, and non-environmental stressors such as socio-economic development and growing populations (Macchi 2010, p.1). The multiple stressors are interlinked and increase the existing pressure on the ecosystem services and natural resources and thus have severe repercussions on SESs (UNEP 2011, p.8). The emergence of climate change adds to the list of stressors and is affecting complex SESs in a variety of ways (Beniston 2003, p.8) and therefore is detrimental to the ability of the local community for coping and adaptive capacity (Macchi 2010, p.18). With changing climate, the possibility to avoid serious harms posed by climate change is almost nonexistent even with a strong ability to adapt to the changes (He 2017, p.110). Such abilities are often challenged due to the absence of appropriate and timely information about the dimension and intensity of changes (Biesbroek et al. 2010, p.445). Now, the integration of science-based evidence and information with adaptation strategies is being discussed to be better equipped to combat the impacts of climate change (Hoppe et al. 2014, p.13).

\section{Information infrastructure in the SESs and the research questions}

\subsection{Information infrastructure in the SESs}

Information about the impact of climate change on mountainous SESs is limited; thereby, the ability of mountain communities to cope and adapt is not appropriately understood (Macchi 2011, p.9). The lack of proper information about climate change impacts and in recognizing local needs and gaps in existing policies and institutional arrangements restricts the decision- and policymakers to form site-specific policies. Therefore, it is imperative to understand communities' response for assessing climate change conditions and increasing policy responses for adaptation (Adger and Vincent 2005, p.401; Smit and Wandel 2006, p.286). Lack of information and effective communication is widely recognized as a limiting factor in socio-economic and ecological development and is one of the major barriers for planning and implementation of strategies (Crabbe and Robin 2006, p.119; Tribbia and Moser 2008, p.316; Lowe et al. 2009, p.4; Carter and Culp 2010, p.36; Archie et al. 2012, Pandey et al. 2018, p.28). Accessibility to relevant information to address the negative impacts of climate change is more important to facilitate adaptation planning (Cruce 2007, p.1, Archie et al. 2012). At the same time, knowing about barriers to access existing information is also important for adaptation planning.
Availability of information does not necessarily mean its successful utilization for decision-making (Pandey et al. 2018, p.28). Information can be split into two parts, supply which includes knowledge and demand which is created by the use of knowledge. Although these two components are highly disconnected in practice for decision-making and adaptation planning (Sarewitz and Pielke 2007, p.6; Dilling 2007, p.49; Dilling and Lemos, 2011, p.681, Archie et al. 2014, p.398). Information infrastructure is defined in a variety of ways depending on the discipline and context (Hanseth 2010, p.123, Pironti, 2006, p.53). Here information infrastructure refers to a technology-enabled foundation or framework that supports the communicative interaction among local communities, stakeholders, policymakers, and the governance at large. Information from the supply side should be scientifically tested, precise, relevant, and easy to communicate so that the demand side understands and uses it appropriately for the desired purpose. The demand side should be well equipped with the mechanism to access and use the available valid information purposefully. Infrastructure like road connectivity, irrigation, institutions, communications mediums, and mechanisms of accessibility for information is traditionally weak and, in most cases, nonexistent at the rural level in the mountains and therefore undermines the flow of information, leading to the development of rural communities (Pandey et al. 2018, p.28). These overall components of information and infrastructure make the information infrastructure for the adaptation planning. Moreover, information supply and demand are context-specific and should be used with caution. The accessibility of information and communication is further challenged due to a variety of reasons such as language, education, and infrastructure (Pandey et al. 2018, p.28). The barriers in many forms from either the demand side or the supply side need to be identified and removed for effective communication and attaining the goal of adaptation to climate change (Scherer and Verburg 2017, p.2). Information about climate change and applicable adaptation strategies is key to address climate change in the Himalayan SESs (Mishra et al. 2019, p.459). The role and barrier of information availability and accessibility to mountain communities are often specific to the regional terms of marginality, remoteness, and high dependence on natural resources (Gerlitz et al. 2017, p.127). Information is a critical factor in the daily life activities and livelihoods of all people and to the development of a community in an SES. The efficacy of decisions made by households and communities to manage the effects of climate variability and change by adapting is critically dependent upon the availability and utility of information (WMO 2011, p.43). The knowledge gained from utilizing the information through different channels and mediums helps in efficient planning of adaptation in both aspects of SES, i.e., socio-economic (such as agriculture, livelihood, and infrastructure) and ecological 
(such as forest conservation, wildlife management, and natural disaster risks and hazards) to cope with the impacts of climate change.

\subsection{Research questions}

Thus, the main objective of the study was to better understand and disclose the role of information infrastructure in climate change adaptation and its underlying barriers in the communities of SES in the Central Himalaya. With a participatory approach to gain insights through mutual learning and exchange with the communities of SES, the study sought to answer the following research questions: (a) What are the socio-economic profiles of the community and the community's perception of climate variability in the SES? (b) How is the availability and utility of information infrastructure in SES for adaptation planning? (c) What are the possible barriers or gaps to climate change adaptation faced by the households? The outcomes will provide pathways to ensure a suitable mechanism for the generation, dissemination, and application of information for climate change adaptation and policy reforms to minimize climate change vulnerability.

\section{The setting of SESs in the Himalaya}

The Himalayan mountains, situated in Asia, are prominent for high-altitude settlements which have distinct physical settings and patterns besides various cultural, structural, and ecological dimensions (Kumar et al. 2021, p.2). The Himalayan region in the last few decades has been facing climate change impacts across the biophysical and social systems (Gerlitz et al. 2017, p.124). The geography and socio-economic settings add to regional vulnerability to various risks and hazards such as climate change with additional stress caused by over-exploitation of natural resources and increased population pressures (Ning et al. 2013, p.4; Singh and Thadani 2015, p.402; ICIMOD 2009, p.1; Ray et al. 2011, p.2; Gupta et al. 2020). Over the last few decades, a rapid increase in intensity and frequency of occurrences of extreme weather events such as increased temperature, altered precipitation patterns, cloudburst, and recurrent episodes of drought has been observed in the Himalaya (Negi et al. 2012, p.347; Xu et al. 2009, p.522; Madhura et al. 2014, p.1158; UAPCC 2014). The forecasted net increase in temperature in the Himalayan region in the 2030s is reported to increase between 1.7 and $2.2{ }^{\circ} \mathrm{C}$ with respect to the 1970s (INCCA 2010, p.41; UAPCC 2014). These environmental changes have already been posing severe threats to water (Pandey et al. 2015, p.1472), agriculture, biodiversity, food security, and human health (Chaudhary and Bawa 2011, p.767; Pandey and Jha 2012, p.490). Specific knowledge and data on human well-being in the rural areas of the Himalaya are limited. However, the climate change effects will be apparent for the communities of SESs in their health, livelihoods, and the availability of natural resources (Sharma et al. 2009, p.2).

With these characteristics in view, the study focused on the village communities of SES in the Central Himalayan and was carried out in the Bageshwar District of Uttarakhand State of India. This area spreads over 2,302 sq $\mathrm{km}$ and lies at the outer ranges of the Central Himalaya between latitudes $29^{\circ} 40^{\prime}$ to $30^{\circ} 20^{\prime} \mathrm{N}$ and longitudes $79^{\circ} 25^{\prime}$ to $80^{\circ} 10^{\prime} \mathrm{E}$. Topographically, the district is characterized by rugged mountains and undulating hills with large areas covered with forest and barren land. The climate is temperate to sub-humid, and the northern part of the district experiences sub-zero temperature almost throughout the year, while the central and southern parts are relatively warm and humid.

The area has a total population of 259,898 (2.58\% of the total Uttarakhand State population) with a population density of 116 per sq. Km (Census of India 2011). Out of the entire district population, $96.51 \%$ are living in villages. The district has a sex ratio of 1093 females for every 1000 males, with a literacy rate of $80.01 \%$. The region has sparsely populated small settlements which have a high dependence on rain-fed agriculture and adjoining forests for natural resources. The agricultural sector is dominated by subsistence farming and is the primary source of livelihood to $68.85 \%$ engaged as cultivators and $7.27 \%$ as agricultural laborers. The high dependency of the communities on natural resources in the region is owing to a lack of access to basic facilities, services, and institutions. For understanding the role of information infrastructure in adaptation planning for climate change, villages were divided into four major categories (Fig. 1). The categories are (1) villages with access to road and having an irrigation facility, (2) villages with access to road and not having an irrigation facility, (3) villages with no access to road and having an irrigation facility, and (4) villages with no access to road and not having an irrigation facility. In total, 11 villages were selected with their geographical location and other spatial information listed in Table 1 (see Fig A1 for the profile of the surveyed villages in Appendix-I). Although situated at different altitudes, these villages have similar challenges, are remotely located, practice similar types of cultivation, have few employment opportunities, and have high forest dependency. 


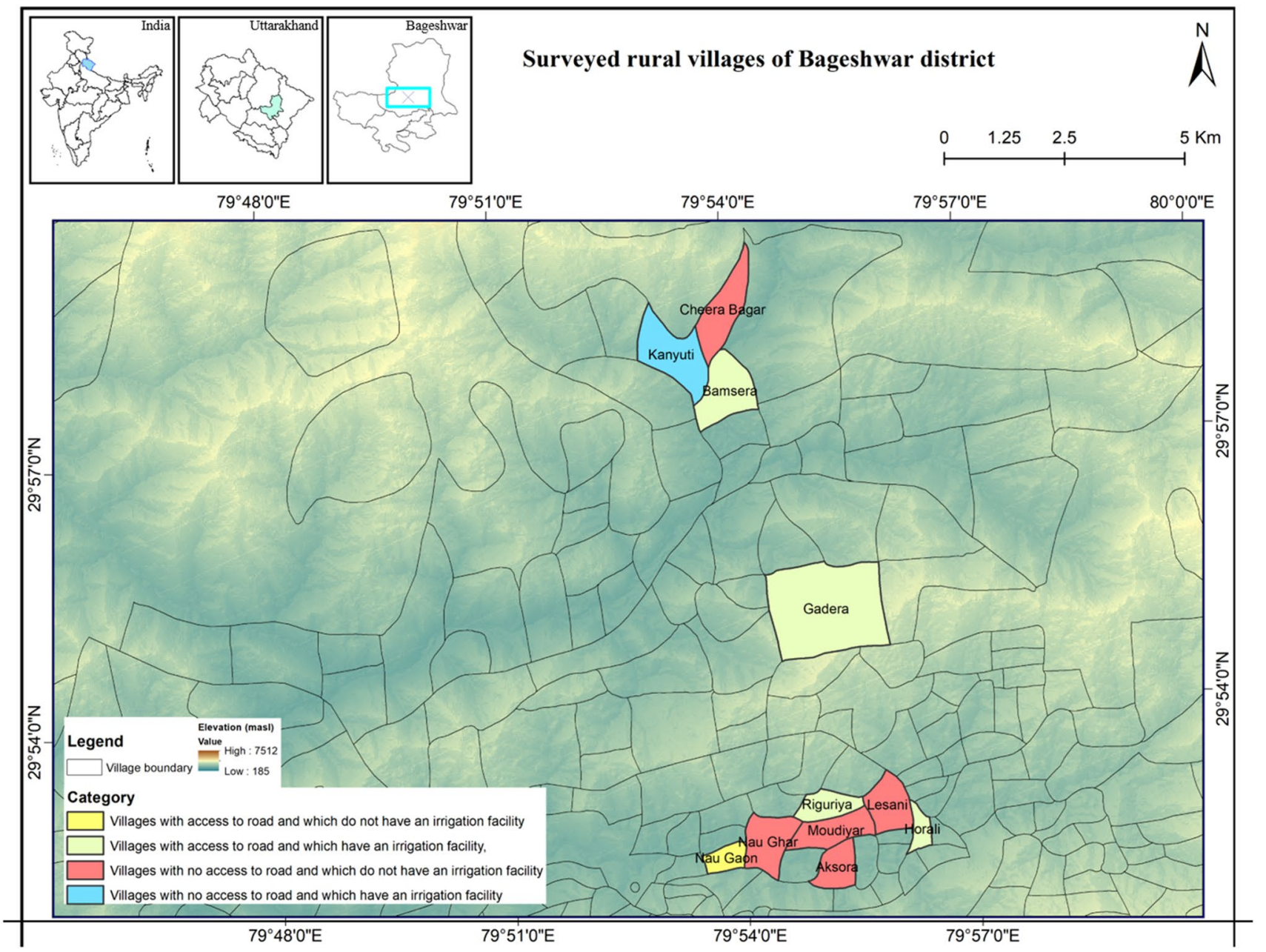

Fig. 1 Surveyed rural villages of the Bageshwar District, Uttarakhand. The villages were divided into four major categories: (1) villages with access to road not having an irrigation facility, (2) villages

\section{Methodology}

\subsection{Sampling, questionnaire, and data collection}

A survey ${ }^{1}$ was conducted using a questionnaire, taking references from previous studies on information-based climate change adaptation planning and implementation (Tribbia and Moser 2008, p.318; Theoharides et al. 2009, p.26; Archie et al. 2012; Pandey et al. 2018, p.30), to collect data on the role of information infrastructure for adaptation planning in the district (see questionnaire in Appendix-II). The investigation began with sharing the objectives of the study and obtaining the informed consent of respondents. Villages in this region contain between 20 and 70 households, and the

\footnotetext{
1 A written informed consent was taken from each respondent for the interview. All interviews were conducted in local language Hindi.
}

with access to road and having an irrigation facility, (3) villages with no access to road and not having an irrigation facility, and (4) villages with no access to road and having an irrigation facility

survey covered approximately about $30 \%$ of the households from each village using stratified random sampling. In all, 85 households were surveyed from 11 villages situated between altitude $1000 \mathrm{~m}$ and $1500 \mathrm{~m}$ in different parts of the region. The questionnaire included 36 questions which were closeended, open-ended, Likert scale, and check-all options. It was divided into four different sections to obtain data on the socio-economic profiles of households, climate change perceptions, household-level decision-making, and information demand. It was also pretested with local people to ensure relevance and ease of comprehension by respondents in the language and structure. The additional data for perception about the change in climate and their response as a means of coping and adaptation practices were collected in the same questionnaire. The heads of households were interviewed, and whenever the household head was not available, the next senior-most member of the household was interviewed as survey respondents because of their acquaintance with the 
Table 1 Spatial details of the surveyed villages

\begin{tabular}{|c|c|c|c|c|}
\hline Category & Village & Latitude & Longitude & $\begin{array}{l}\text { Altitude } \\
\text { (masl) }\end{array}$ \\
\hline \multirow[t]{4}{*}{1} & Bamsera & $\begin{array}{l}29^{\circ} 57^{\prime} 49.1^{\prime \prime} \\
\mathrm{N}\end{array}$ & $79^{\circ} 53^{\prime} 52^{\prime \prime} \mathrm{E}$ & 1078 \\
\hline & Gadera & $\begin{array}{l}29^{\circ} 52^{\prime} 28.4^{\prime \prime} \\
\mathrm{N}\end{array}$ & $79^{\circ} 56^{\prime} 2.3^{\prime \prime} \mathrm{E}$ & 1187 \\
\hline & Horali & $\begin{array}{l}29^{\circ} 52^{\prime} 47.3^{\prime \prime} \\
\mathrm{N}\end{array}$ & $\begin{array}{l}79^{\circ} 56^{\prime} 20.8^{\prime \prime} \\
\text { E }\end{array}$ & 1247 \\
\hline & Riguriya & $\begin{array}{l}29^{\circ} 52^{\prime} 16.9^{\prime \prime} \\
\mathrm{N}\end{array}$ & $\begin{array}{l}79^{\circ} 54^{\prime} 58.6^{\prime \prime} \\
\text { E }\end{array}$ & 1210 \\
\hline 2 & Naugaon & $\begin{array}{l}29^{\circ} 52^{\prime} 16.5^{\prime \prime} \\
\mathrm{N}\end{array}$ & $\begin{array}{l}79^{\circ} 55^{\prime} 10.1^{\prime \prime} \\
\mathrm{E}\end{array}$ & 1165 \\
\hline 3 & Kanyuti & $29^{\circ} 57^{\prime} 56^{\prime \prime} \mathrm{N}$ & $\begin{array}{l}79^{\circ} 53^{\prime} 51.4^{\prime \prime} \\
\mathrm{E}\end{array}$ & 1221 \\
\hline \multirow[t]{5}{*}{4} & Aksora & $\begin{array}{l}29^{\circ} 52^{\prime} 27.0^{\prime \prime} \\
\mathrm{N}\end{array}$ & $79^{\circ} 55^{\prime} 5.6^{\prime \prime} \mathrm{E}$ & 1249 \\
\hline & CheeraBagar & $\begin{array}{l}29^{\circ} 58^{\prime} 14.4^{\prime \prime} \\
\mathrm{N}\end{array}$ & $\begin{array}{l}79^{\circ} 54^{\prime} 19.8^{\prime \prime} \\
\mathrm{E}\end{array}$ & 1109 \\
\hline & Lesani & $29^{\circ} 53^{\prime} 2.6^{\prime \prime} \mathrm{N}$ & $\begin{array}{l}79^{\circ} 55^{\prime} 23.4^{\prime \prime} \\
\mathrm{E}\end{array}$ & 1456 \\
\hline & Moudiyar & $\begin{array}{l}29^{\circ} 52^{\prime} 30.1^{\prime \prime} \\
\mathrm{N}\end{array}$ & $\begin{array}{l}79^{\circ} 54^{\prime} 56.9^{\prime \prime} \\
\mathrm{E}\end{array}$ & 1290 \\
\hline & Naughar & $\begin{array}{l}29^{\circ} 52^{\prime} 14.5^{\prime \prime} \\
\mathrm{N}\end{array}$ & $\begin{array}{l}79^{\circ} 55^{\prime} 11.4^{\prime \prime} \\
\mathrm{E}\end{array}$ & 1195 \\
\hline
\end{tabular}

prevailing mechanism and livelihood options. Each interview lasted between 30 and $45 \mathrm{~min}$, and the answers were recorded on the questionnaire sheet by the interviewer.

\subsection{Data analysis}

The data obtained were coded and analyzed using R-software using the "factoextra" and "ggplot2" packages for statistical analysis and data visualization for frequency distribution and correlation. Analysis of qualitative data from the in-depth interviews involved field notes, audio recordings, and coding and then linking these to theoretical concepts as per the research objectives. To present the complex view of interview participants on the research objectives, some verbatim statements of the study participants were directly quoted from the transcripts. Some responses were quantified and were converted into frequency scores and calculated into a percentage among the different village categories.

\section{Answers to the research questions}

\subsection{Community profile and perceptions}

\subsubsection{Community profile}

The survey result showed that $55.3 \%$ of respondents were male and $44.7 \%$ female. The sex ratio was 0.92 in the household members. The maximum and minimum age of the household respondent was 68 and 19 years old, respectively. The status of education was poor as $30 \%$ of illiteracy was reported among the households in the villages which have no access to roads and those without irrigation facilities. In the mountainous region, family size is generally large as it ensures the availability of family labor. In this region, the mean family size was $6.34( \pm 0.396)$.

Generally, households in the region have more than one livelihood option for achieving subsistence livelihood and the majority of them, i.e., $80 \%$, are practicing agriculture as their primary profession. Villages having irrigation facilities have $78 \%$ of households practicing agriculture. Labor works account for $36 \%$ of the villages which lack connectivity to road and irrigation. Labor work indicates the low economic conditions of the community. Forty-seven percent of the land is unirrigated, $10 \%$ of the land is uncultivated, and only $43 \%$ of the land is irrigated properly, as reported by respondents. Cultivable land accounts more in the villages where irrigation is available and feasible. Traditional varieties of crops are facing a high risk as a change in climate causing low production.

\subsubsection{Perception of community on climate change on key sectors and associated risks}

In the survey, $96 \%$ of the respondents reported that the pattern of the weather is changing when respondents were asked about whether the pattern of weather is changing or not. Out of these, only $33 \%$ of villagers understand climate change. Furthermore, they reported the different changes in the surrounding environment by adjudging the changes in climatic parameters (Table 2).

\subsubsection{Key challenges faced by the mountain communities}

For identifying the significant socio-economic and ecological challenges currently faced by the community, respondents were asked to know about villager's perspectives on climate change (Table 3 ). In the socio-economic challenges, lack of political will and economic issues were the most prevalent challenges faced by the community. In ecological 
Table 2 Perception of communities on the environmental changes

\begin{tabular}{|c|c|c|c|}
\hline Feature & $\begin{array}{l}\text { Respond- } \\
\text { ents }(\%)\end{array}$ & $\begin{array}{l}\text { Increased }(+) \text { or } \\
\text { decreased }(-)\end{array}$ & Change(s) \\
\hline Temperature & 75 & + & Extreme temperature; shorter and severe winters \\
\hline Rainfall & 83 & + & Intensity; duration; frequency; and timing \\
\hline Snowfall & 69 & - & Amount and intensity; drier winters \\
\hline $\begin{array}{l}\text { Land quality } \\
\text { and agricul- } \\
\text { ture }\end{array}$ & 79 & - & $\begin{array}{l}\text { Reduction in agricultural productivity and production; increased migration; excessive destruction } \\
\text { by wild animals }\end{array}$ \\
\hline Water & 93 & - & $\begin{array}{l}\text { Low groundwater recharge; drying of water sources; reduced water levels; reduction in soil mois- } \\
\text { ture }\end{array}$ \\
\hline Forests & 96 & - & Broad-leaved species disappearance; deforestation \\
\hline Disasters & 75 & + & Intensity and frequency increased \\
\hline
\end{tabular}

Table 3 Socio-ecological challenges faced by the mountain communities

\begin{tabular}{lcll}
\hline Socio-economic challenges & Frequency $(\%)$ & Ecological challenges & Frequency $(\%)$ \\
\hline Economic pressure & 88.25 & Water quantity/quality & 92.5 \\
Population pressure & 3.25 & Land quality/fragmentation & 63.25 \\
Social cohesion & 26.5 & Change in precipitation & 98 \\
Political will & 95.25 & Change in temperature & 63.75 \\
Tourism inflow & 2.25 & Forest fire & 91.75 \\
\hline
\end{tabular}

challenges, change in precipitation, water quality and quantity, and forest fire were the most common issues.

According to $92 \%$ of respondents, the negative impact of change in climate on the community was more than the positive impact. Also, the consequences of climate change were broader in many aspects including cultivation. To accurately assess the perceptions of the vulnerability of the local community to climate change, respondents were asked to rate the degree of potential key impacts of climate change on their community. The villagers reported that there is a high possibility of negative impacts on forest ecosystem, resulting in less rainfall, negative impact on wildlife and increase in the frequency of wildlife conflict, negative impact on water quantity and quality, increase in local air temperature, and a decrease in snowfall (Fig. 2).

\subsection{Information infrastructure}

\subsubsection{Availability and utility of information infrastructure}

The villagers use information in a differential manner (Fig. 3). The available infrastructure for information dissemination solely depends on the availability of information products and services (i.e., information sources). The

\footnotetext{
${ }^{2}$ Krishi Vigyan Kendra (KVK) is an agricultural extension center in India. These centers are associated with a local agricultural university and serve as the ultimate link between the Indian Council of Agricultural Research (ICAR) and farmers and aim to apply agricultural research in a practical, localized setting.
}

information sources in the study area are newspaper, television, radio, mobile, Krishi Vigyan Kendra ${ }^{2}$ (agriculture extension center-KVK), village elders, gram sabhas [a body constituting of persons whose names are included in the electoral rolls of the Panchayat (a village council in India) at the village level], nearby villagers, governmental officials, and the Internet. Availability of information infrastructure and its utility varied remarkably in the different communities. The availability of information infrastructure was more in villages with road accessibility than in villages without road accessibility. When comparing availability based on the irrigation facility, villages with irrigation have better availability of information than those without irrigation. Information utility is more in the villages which have road connectivity showing the use of information for the adaptation planning and in their daily life activities. The demand for information was more in the villages which lack infrastructural facilities. Information infrastructure for these villages was mostly unavailable and was not being utilized. One of the most promising sources for getting information nowadays is mobile phones. It was found during the survey that almost every household has a mobile phone. Mobile phones allow villagers to obtain information useful for them using specific helplines, Short Message Service (SMS), and the Internet. Though their availability was more, their utility for getting information was very low in the study area due to low awareness and illiteracy. 


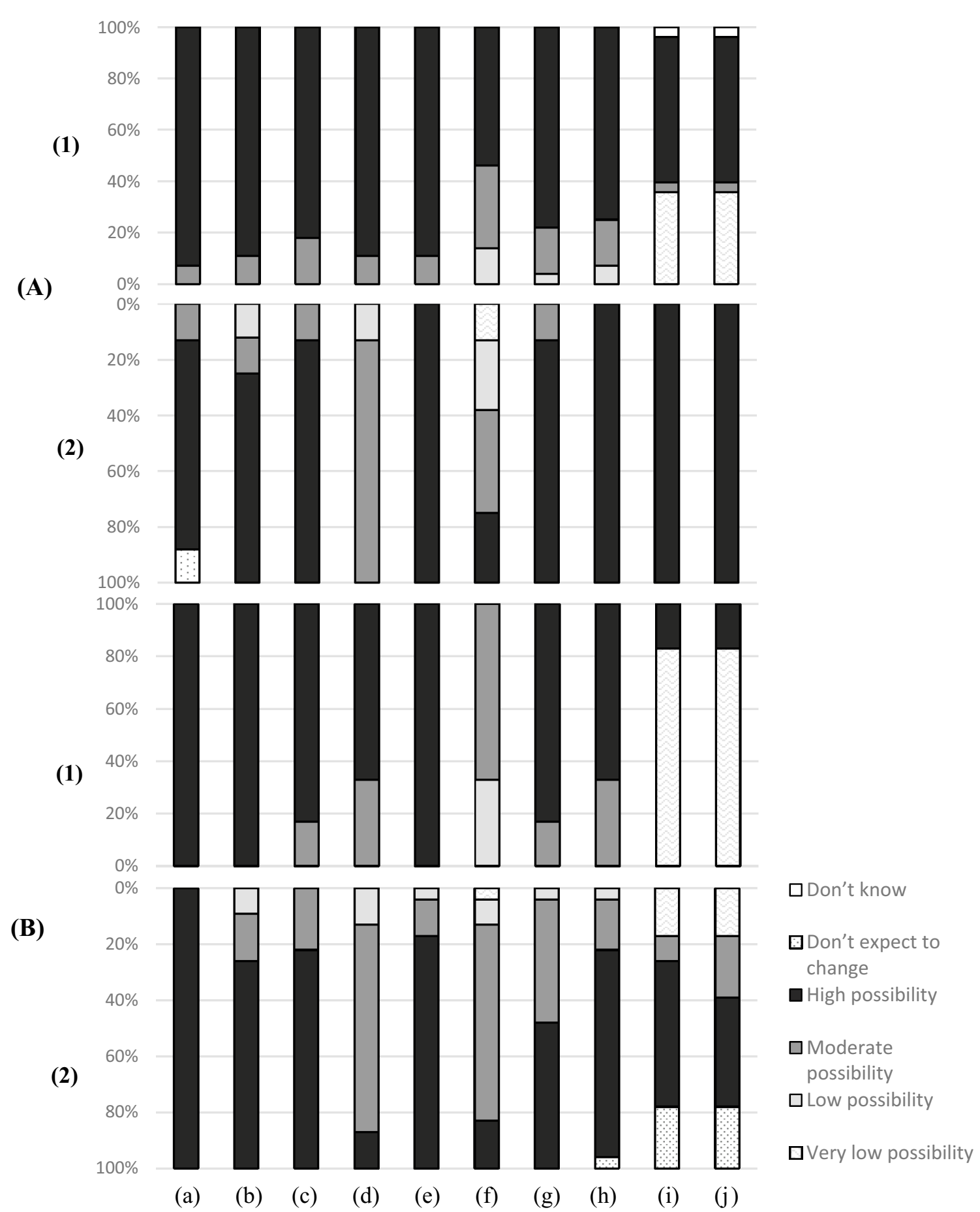

Fig. 2 Degree of impacts of climate change on (a) local forest ecosystem, (b) local rainfall/cloudburst, (c) local wildlife, (d) local water quality/quantity, (e) local potential for forest fire, (f) local air tem-

perature, (g) agriculture practices, (h) livestock, (i) snowfall, (j) snow runoff/melting time, [A without access to road, $\mathbf{B}$ with access to road; (1) without irrigation, (2) with irrigation] reported by the community

"Nowadays the information is available through multiple sources but people do not know how to utilize that information in their daily life activities due to low literacy and awareness. Mobile phones are now becomcies should focus more on the application of provided information."-Shrikrishna Joshi—a respondent from Lesani village. 
(1)

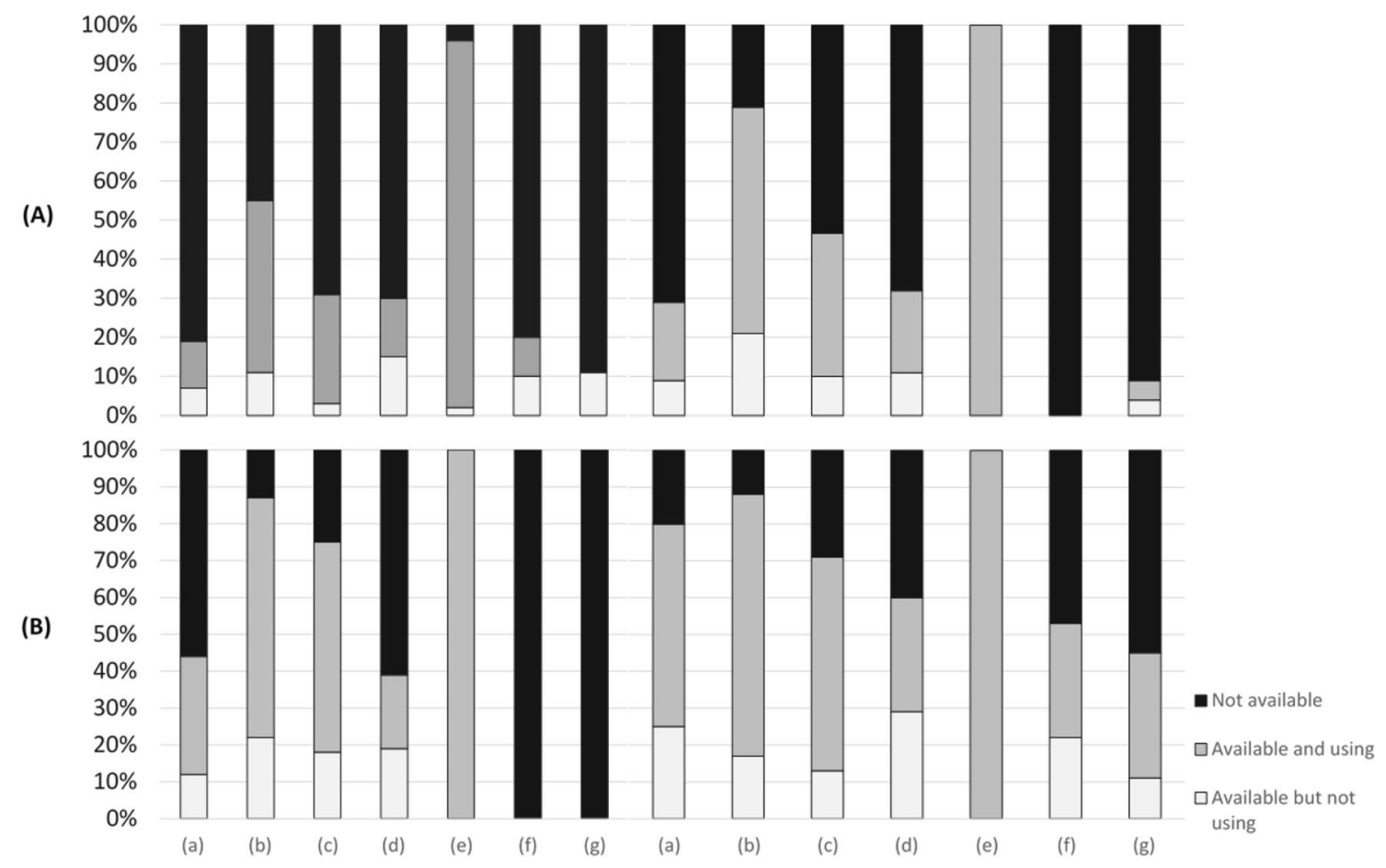

Fig. 3 Information infrastructure availability and utility by the community: (a) newspaper, (b) television, (c) satellite dish/cable, (d) radio, (e) mobile, (f) Internet, (g) KVK; [A without access to road,
(2)

B with access to road; (1) without irrigation, (2) with irrigation]. The availability and utility of information infrastructure were more in villages with road accessibility and irrigation facility

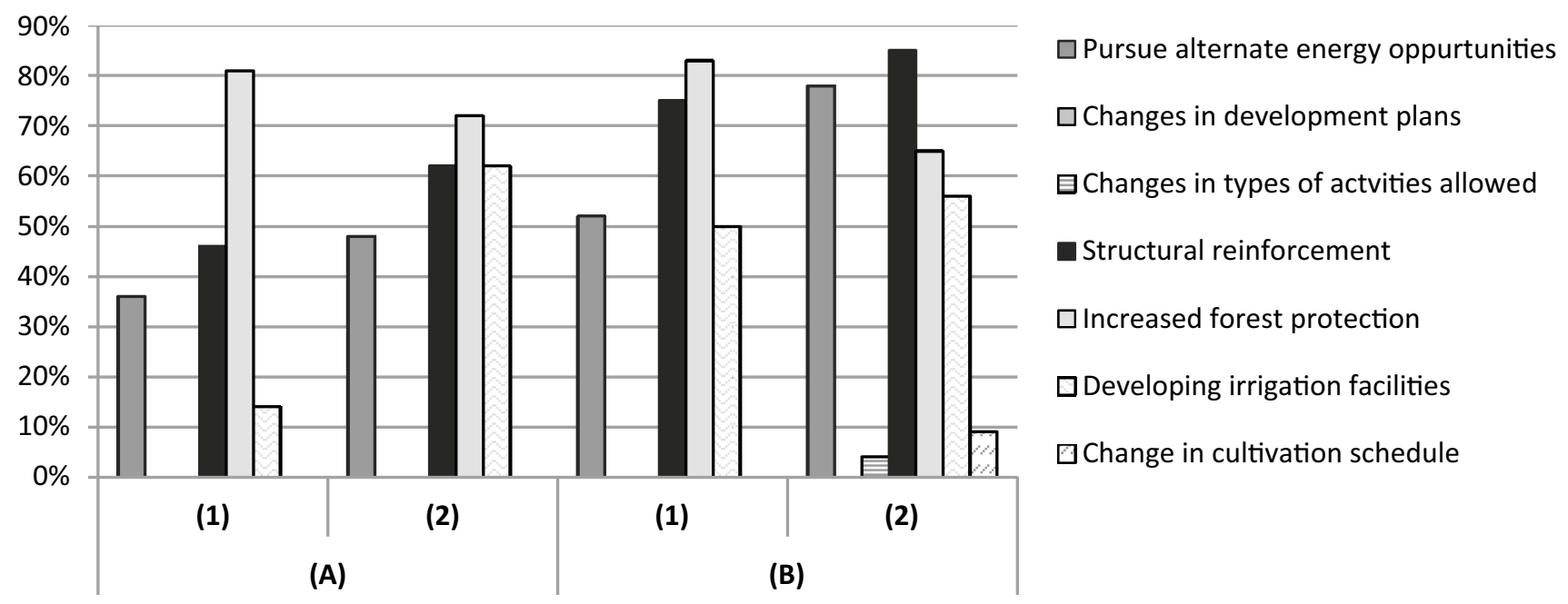

Fig. 4 Changes by the community in response to climate change [A without access to road, $\mathbf{B}$ with access to road; (1) without irrigation, (2) with irrigation]. The majority of the changes were reported in the villages with road accessibility and irrigation facilities

\subsubsection{Information infrastructure application in adaptation}

Eighty-seven percent of the respondents reported that they need information for adaptation strategies, and $97 \%$ reported that the local information scale is useful in planning for adaptation. $79.5 \%$ of respondents from all categories reported that information provided by the nearby communities sometimes affects their decision-making. 


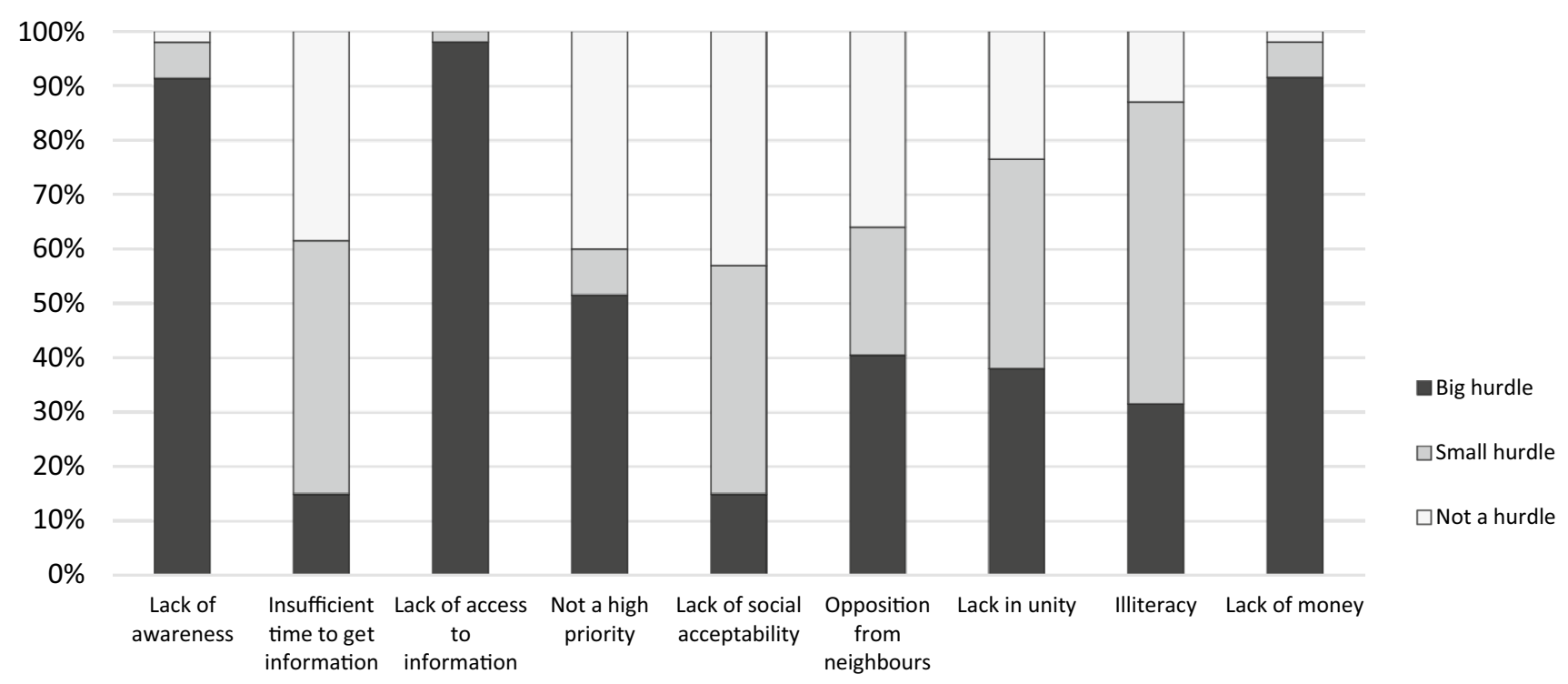

Fig. 5 Major barriers identified in information demand and flow. Lack of information, awareness, and money are the major barriers in adaptation planning by the communities

The use of alternate energy, structural reinforcement, and increased forest protection are the three most common responses received by households in response to climate change (Fig. 4). Increased forest protection was more in the villages without irrigation facility, indicating that forest was of immense value for them. Structural reinforcement and use of alternate energy are seen more in the villages with road connectivity which indicates easy availability of required resources. (Few examples of changes by the community in response to climate change are shown in Fig. A2 in Appendix-I.)

\subsection{Barriers in adaptation planning}

The major barriers identified in information demand and flow are lack of awareness or understanding, insufficient time to get information about or plan for potential changes, lack of access to information, low priority in community and household, lack of social acceptability of information that takes climate change into account, opposition from neighbors, lack of money and illiteracy. Overall, lack of access to information, lack of money, and lack of awareness or poor understanding were identified as the three most common barriers in information demand and flow among all the communities (Fig. 5). Lack of unity and literacy were also listed as two important barriers for communities for the availability and utility of information for adapting to climate change.
"Awareness programs can substantially help local communities to gain information and knowledge towards climate change adaptation. The lack of information is mainly due to low awareness in the people. The number and frequency of awareness program is very limited and generally escapes our participation due to their low visibility."-Pratap Ram, a respondent from Nau Ghar village

\section{Impacts of information infrastructure}

\subsection{Current scenario}

Although these villages were located at different altitudes, they all have identical challenges such as remote location, few livelihood opportunities, and practicing homogenous cultivation and were highly dependent on forests (Gerlitz et al. 2017, p.135; Chakraborty et al. 2018, p.504). They were different with respect to the available facilities and infrastructure. These infrastructure facilities (road connectivity, irrigation, institutions, and communications) can drive the adaptive capacity of the communities to climate change to high or low according to their availability (Barua et al. 2014, p.274; Kelkar et al. 2008, p.571). It is a strange paradox that in Uttarakhand, a mountain state, with only $10 \%$ 
of the land as agricultural land (in hills $6 \%$ and foothills $4 \%$ ), over $70 \%$ of the population is engaged in agricultural activities as cultivators and laborers (Census of India 2011). Irrigation was available only in half of the villages surveyed, mostly by canals and pipeline. These facilities were never being utilized at their full capacity due to poor management and low water availability (Scott et al. 2019, p.277). Most climate change discussions in these villages focused on change in precipitation pattern and decrease in water quantity. While weather change is not a new experience, and people are coping and adapting to these changes, they are not able to list the measures being taken. Hence, there is limited information on their responses to such changes, sources of information, and utilization of resources to minimize climatic risks. Moreover, there is a lack of information on the socio-economic factors that enhance or inhibit people's capacities to adapt (Roncoli et al. 2002, p.410; Ziervogel et al. 2005, p.2; Hansen et al. 2009, p.80). It is compelling to understand the adaptation strategies practice by the households given their low education status and lack of information (Pandey et al. 2018, p.33). Village communities in the Central Himalaya have witnessed changes in climate in the last 20-25 years (Tewari et al. 2017, p.2). Mainly, the respondents consider a change in the local weather conditions as climate change. Knowledge of climate change was more in villages with better information infrastructure. In all, the majority of the respondents lack knowledge about climate change. However, the respondents do not truly understand these changes like climate change, but they are aware of the problems and the implications. The communities are aware that changes in local temperature and precipitation can be attributed to human activities such as deforestation and pollution. The major socio-economic and ecological challenges faced by the communities imply that there is a lack of resources, which further have direct impacts on information infrastructure. Good governance, i.e., how public institutions conduct public affairs and manage public resources in a preferred way, and good economic condition will assist to increase information availability and its meaningful utility through local institutional networks (Gerlitz et al. 2017, p.135; Pandey and Jha, 2012, p.504; Macchi et al. 2014, p.10). Water availability is a major problem due to deforestation for development projects, and such ecological challenges cause an indirect effect on information demand and its flow, resulting in low adaptive capacity (Kelkar et al. 2008, p.570; Munsi et al. 2012, p.620; Reddy et al. 2013, p.1493; Ogra and Badola 2015, p.520).

\subsection{Does information promote adaptation?}

There is ample literature that suggests information alone does not necessarily promote changes in adaptation as to how the information is communicated and utilized is extremely important (Andersson and Keskitalo 2018, p.82). Information is mainly used for daily activities, but still, it is required and used by communities for climate change adaptation planning (Pandey et al. 2018, p.33). It is because the villagers need climate-related information for planning, developing, and creating a framework for adaptation. The adaptation planning generally revolves around the cultivation and rearing of livestock for Himalayan communities. The use of information for adaptation planning was more in the villages with better resource availability and better connectivity through the road. Usage of information was very low in the villages without road connectivity. It indicates that road connectivity plays a vital role in adaptation planning as the information and the resources required are readily available in those villages (Pandey et al. 2018, p.29). Moreover, the non-availability of roads restricts transportation, leading to low plying of vehicles and thereby undermining the connectivity with the nearest market or information contained locations. The low road connectivity refrains community members to interact with each other, therefore restricting the information sharing among themselves.

Despite information infrastructure availability, its utility is more important for the communities to cope up with climate change. Information infrastructure is present in the communities for providing information, but only a few respondents knew how to retrieve and access the information from the existing information infrastructure. Barriers to the access of information would prevent proper communication and information flow. They reported that information is present in the community, but somehow it is not accessible for usage. These challenges are more in communities where road connectivity is not present, resulting in poor one-toone interaction. Information accessibility requires specific knowledge so that it can be utilized efficiently for adaptation planning. Most of the villagers are not equipped with such knowledge due to their poor education levels. The changes made by the community to climate change were very similar to what Pandey et al. (2018) reported for adaptation planning in the Uttarakhand Himalayan state. Earlier studies have highlighted that decisions regarding the adaptation can be contagious which results from flowing information (Fussel 2007, p.268; Archie 2013, p.583). Precise, timely, and reliable information is vital for both the development of the individuals and the community at large. Correct, comprehensive, and conveniently usable information helps an individual to plan work properly and execute it timely. Moreover, improving access to climate information to rural people is an effective strategy for improving livelihood under the impacts of climate change (Mengistu 2011, p.144). Climate change requires increasing the resistivity and adaptive capacity of communities and ecosystems for making them adapt to these multi-dimensional changes (Tompkins and Adger 2004), more so, because climate variability and 


\section{Un-informed System}

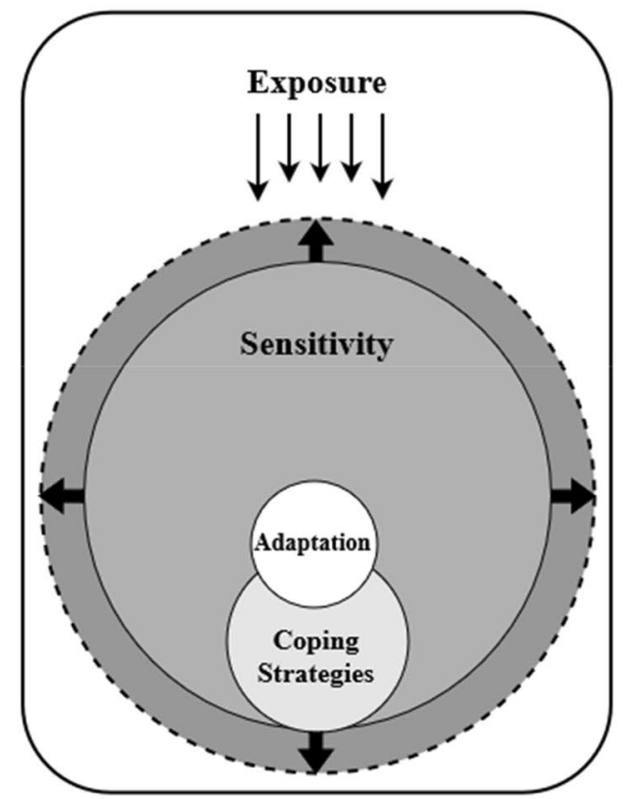

Informed System

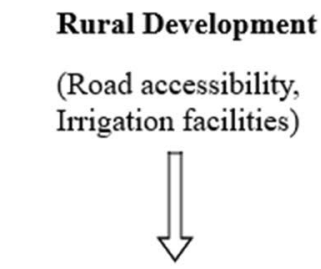

Information Demand

Information Availability

Information Access

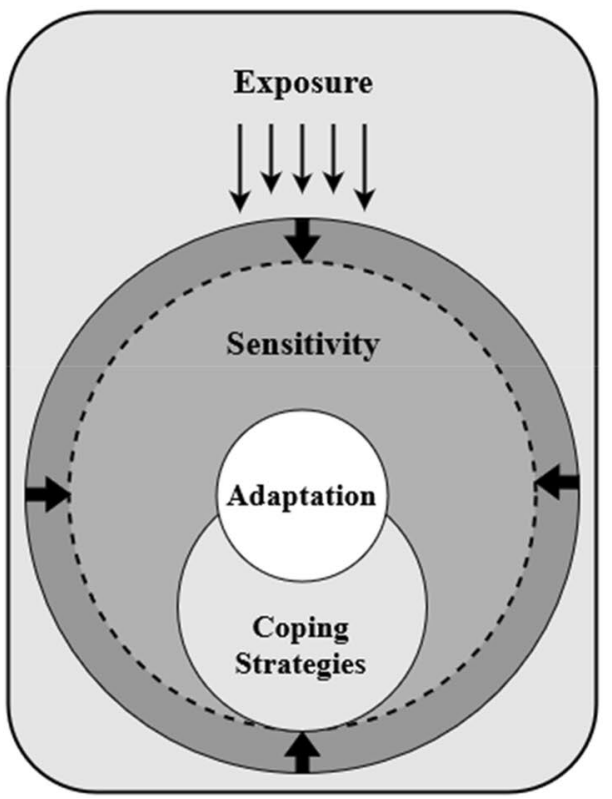

Fig. 6 Role of information infrastructure on the un-informed system. Availability of information infrastructure decreases the sensitivity and increases the adaptive capacity of a system (Adapted from Pandey et al. 2018)

changes have substantial impacts on the natural resources and fragile ecosystems of mountains (Tse-ring et al. 2010, p.15).

\subsection{Lesson learned}

The study was undertaken to assess the availability and utility of information infrastructure and to identify the barriers in information demand and flow. The findings of this study reveal that there are remarkable differences in the villages based on road accessibility and irrigation facility. The differences were observed in the literacy levels (low education status in the villages with no road connectivity and no irrigation), profession (mostly agriculture in the villages with irrigation facility), agriculture practices, and production (good production was observed in the villages with road connectivity and irrigation facility), livestock (more in villages with no road connectivity and no irrigation), and economic conditions of communities (low-income group in the villages with no road connectivity and no irrigation). These communities also showed different opinions and perceptions of climate change. Road connectivity plays a major role in information infrastructure development and efficient utilization of information in adaptation planning. Road-accessible villages had good information infrastructure as the road is used as a channel for easy availability of resources. Furthermore, irrigation also has an indirect effect on information available for adaptation planning. Villages with better irrigation facilities had excellent agricultural production which provides good resources to build up information infrastructure. Communities which lack road accessibility and irrigation are vulnerable to climate change and require a basic information infrastructure. Information demand was more in those villages, but its availability was very low.

While assessing the availability and utility of information infrastructure, it was found that information in the villages is mostly available through television, mobile, newspaper, and village elders. Its availability and utility were more in villages with road connectivity and irrigation facilities. The importance of information infrastructure cannot be overemphasized since the prevalent profession of these communities is agriculture and livestock farming, which is climate-sensitive. Hence, the production quality, quantity, and economic condition of these villages lie in how well they can access suitable information and adapt to climate change.

\section{Outlook}

This study has emphasized the role of information infrastructure and barriers in adaptation planning as well as resolving the precarious condition of communities, specifically for climatic and livelihood parameters of the Central Himalaya. The resulting framework (Fig. 6) could be adopted in the entire Himalayan region and for other mountain ecosystems of the world. The high exposure of these systems to climate-related risks and hazards urgently needs to decrease their vulnerability for a sustainable livelihood. 
Information can bridge the gap between adaptation strategies and planning at the community or household levels to address the criticality of climate change, resulting in reducing the vulnerability of an exposed system as deduced from the study. The information for adaptation planning can be of different types such as technology, awareness, education of climate change, or innovative ideas. The adaptive capacity increases and sensitivity decreases with an increase in information flow. Sufficient information infrastructure at a micro-level like households can act as a major tool for an un-informed exposed system to become a less vulnerable informed system to climate change. It has also been reiterated that climate risk information should be based on the daily activities of rural communities to make information meaningful and relevant (Mengistu 2011, p.144). Indigenous, local, and traditional knowledge systems and practices, including indigenous peoples' holistic view of community and environment, are a major resource for adapting to climate change. Natural resource-dependent communities have a long history of adapting to highly variable and changing social and ecological conditions. Integrating such forms of knowledge with existing practices with the use of information increases the effectiveness of adaptation. Therefore, it would be desired that policy perspective must revolve around the development of basic information infrastructural facilities which helps in providing information for adapting to the changes.

Supplementary Information The online version contains supplementary material available at https://doi.org/10.1007/s42532-021-00096-1.

Funding Open Access funding enabled and organized by Projekt DEAL.

\section{Declarations}

Conflict of interest The authors declare no conflict of interest.

Open Access This article is licensed under a Creative Commons Attribution 4.0 International License, which permits use, sharing, adaptation, distribution and reproduction in any medium or format, as long as you give appropriate credit to the original author(s) and the source, provide a link to the Creative Commons licence, and indicate if changes were made. The images or other third party material in this article are included in the article's Creative Commons licence, unless indicated otherwise in a credit line to the material. If material is not included in the article's Creative Commons licence and your intended use is not permitted by statutory regulation or exceeds the permitted use, you will need to obtain permission directly from the copyright holder. To view a copy of this licence, visit http://creativecommons.org/licenses/by/4.0/.

\section{References}

Adger WN, Vincent K (2005) Uncertainty in adaptive capacity. CR Geosci 337(4):399-410
Andersson E, Keskitalo ECH (2018) Adaptation to climate change? Why business as usual remains the logical choice in Swedish forestry. Glob Environ Chang 48:76-85

Archie KM (2013) Mountain communities and climate change adaptation: barriers to planning and hurdles to implementation in the Southern Rocky Mountain Region of North America. Mitig Adapt Strat Glob Change 19(5):569-587

Archie KM, Dilling L, Milford JB, Pampel F (2012) Climate change and western public lands: a survey of U.S. federal land managers on the status of adaptation efforts. Ecol Soc 17(4):20

Archie KM, Dilling L, Milford JB, Pampel FC (2014) Unpacking the "information barrier": comparing perspectives on information as a barrier to climate change adaptation in the interior mountain west. Ecol Lett 133:397-410

Barua A, Katyaini S, Mili B, Gooch P (2014) Climate change and poverty: building resilience of rural mountain communities in south Sikkim, eastern Himalaya, India. Reg Environ Change 14(1):267-280

Beniston M (2003) Climatic change in mountain regions: a review of possible impacts. Clim Change 59:5-31

Biesbroek GR, Swart RJ, Carter TR, Cowan C, Henrichs T, Mela H, Morecroft MD, Rey D (2010) Europe adapts to climate change: comparing national adaptation strategies. Glob Environ Change 20(3):440-450

Carter R, Culp S (2010) Planning for climate change in the west. Lincoln Institute of Land Use Policy, Cambridge

Census of India (2011) Office of the registrar general and census commissioner. Government of India, New Delhi

Chakraborty A, Joshi PK, Sachdeva K (2018) Capturing forest dependency in the central Himalayan region: variations between Oak (Quercus spp.) and Pine (Pinus spp.) dominated forest landscapes. Ambio 47(4):504-522

Chaudhary P, Bawa KS (2011) Local perceptions of climate change validated by scientific evidence in the Himalayas. Biol Lett 7(5):767-770

Crabbe P, Robin M (2006) Institutional adaptation of water resource infrastructures to climate change in eastern Ontario. Clim Change 78:103-133

Cruce TL (2007) Adaptation Planning: What U.S. States and Localities Are Doing? Pew Center on Global Climate Change, Arlington, VA

Dilling L (2007) Towards science in support of decision making: characterizing the supply of carbon cycle science. Environ Sci Policy 10:48-61

Dilling L, Lemos MC (2011) Creating usable science: opportunities and constraints for climate knowledge use and their implications for science policy. Glob Environ Change 21(2):680-689

Fussel HM (2007) Adaptation planning for climate change: concepts, assessment approaches, and key lessons. Sustain Sci 2(2):265-275

Gerlitz J-Y, Macchi M, Brooks N, Pandey R, Banerjee S, Jha SK (2017) The Multidimensional Livelihood Vulnerability Indexan instrument to measure livelihood vulnerability to change in the Hindu Kush Himalayas. Clim Dev 9(2):124-140

Gupta KA, Negi M, Nandy S, Kumar M, Singh V, Donatella V, Petrosillo I, Pandey R (2020) Mapping socio-environmental vulnerability to climate change in different altitude zones in the Indian Himalayas. Ecol Indic 109(2020):105787

Hansen JW, Mishra A, Rao KPC, Indeje M, Ngugi RK (2009) Potential value of GCM-based seasonal rainfall forecasts for maize management in semiarid Kenya. Agric Syst 101:80-90

Hanseth O (2010) From systems and tools to networks and infrastructures-from design to cultivation: towards a design theory of information infrastructures. In: Industrial informatics design, use and innovation: perspectives and services, pp 122-156

He XJ (2017) Information on impacts of climate change and adaptation in China. J Environ Inf 29(2):110-121 
Hoppe T, van den Berg MM, Coenen FH (2014) Reflections on the uptake of climate change policies by local governments: facing the challenges of mitigation and adaptation. Energy Sustain Soc 4:8

ICIMOD (2009) The changing Himalayas: impact of climate change on water resources and livelihoods in the Greater Himalayas. ICIMOD, Kathmandu

INCCA (2010) Climate change and India: A $4 \times 4$ assessment. A sectoral and regional analysis for 2030S. Ministry of Environment, Forests and Climate Change, Government of India, New Delhi

IPCC (2014) Climate change 2014: synthesis report. In: Pachauri RK, Meyer LA (eds) Contribution of working groups I, II and III to the fifth assessment report of the intergovernmental panel on climate change. IPCC, Geneva

Joshi AK, Joshi PK (2019) Forest ecosystem services in the Central Himalaya: local benefits and global relevance. Proc Natl Acad Sci India Sect B Biol Sci 89:785-792

Kelkar U, Narula KK, Sharma VP, Chandna U (2008) Vulnerability and adaptation to climate variability and water stress in Uttarakhand State, India. Glob Environ Change 18(4):564-574

Kumar P, Fürst C, Joshi PK (2021) Socio-ecological systems (SESs)-identification and spatial mapping in the Central Himalaya. Sustainability 13:7525

Lowe A, Foster J, Winkelman S (2009) Ask the climate question: adapting to climate change impacts in urban regions. Center for Clean Air Policy, Washington, DC

Macchi M (2010) Mountains of the world-ecosystem services in a time of global and climate change. ICIMOD, Kathmandu

Macchi M (2011) Framework for community-based climate vulnerability and capacity assessment in mountain areas. ICIMOD, Kathmandu

Macchi M, Gurung AM, Hoermann B (2014) Community perceptions and responses to climate variability and change in the Himalayas. Climate and Development, (November), pp 37-41

Madhura RK, Krishnan R, Revadekar JV, Mujumdar M, Goswami BN (2014) Changes in western disturbances over the western Himalayas in a warming environment. Clim Dyn 44(3-4):1157-1168

Mengistu DK (2011) Farmers' perception and knowledge on climate change and their coping strategies to the related hazards: case study from Adiha, central Tigray, Ethiopia. Agric Sci 2:138-145

Mishra A et al (2019) Adaptation to climate change in the Hindu Kush Himalaya: stronger action urgently needed. In: Wester P, Mishra A, Mukherji A, Shrestha A (eds) The Hindu Kush Himalaya assessment: mountains, climate change, sustainability and people. Springer, Berlin, pp 457-490

Munsi M, Areendran G, Joshi PK (2012) Modeling spatio-temporal change patterns of forest cover: a case study from the Himalayan foothills (India). Reg Environ Change 12(3):619-632

Negi GCS, Samal PK, Kuniyal JC, Kothyari BP, Sharma RK, Dhyani PP (2012) Impact of climate change on the western Himalayan mountain ecosystems: an overview. Trop Ecol 53(3):345-356

Ning W, Rawat GS, Joshi S, Ismail M, Sharma E (2013) High-altitude rangelands and their interfaces in the Hindu Kush Himalayas. ICIMOD, Kathmandu

Ogra MV, Badola R (2015) Gender and climate change in the Indian Himalayas: global threats, local vulnerabilities, and livelihood diversification at the Nanda Devi biosphere reserve. Earth Syst Dyn 6(2):505-523

Pandey R, Jha SK (2012) Climate vulnerability index-measure of climate change vulnerability to communities: a case of rural Lower Himalaya, India. Mitig Adapt Strat Glob Change 17(6):487-506
Pandey R, Kala S, Pandey VP (2015) Assessing climate change vulnerability of water at household level. Mitig Adapt Strat Glob Change 20(8):1471-1485

Pandey R, Kumar P, Archie KM, Gupta AK, Joshi PK, Valente D, Petrosillo I (2018) Climate change adaptation in the westernHimalayas: household level perspectives on impacts and barriers. Ecol Ind 84:27-37

Pironti JP (2006) Key elements of a threat and vulnerability management program. Inf Syst Audit Control 3:52-56

Ray M, Doshi N, Alag N, Sreedhar R (2011) Climate vulnerability in North Western Himalayas. Indian Network on Ethics and Climate Change (INECC), Visakhapatnam

Reddy C, Dutta K, Jha CS (2013) Analysing the gross and net deforestation rates in India. Curr Sci 105(11):1492-1500

Roncoli C, Ingram K, Kirshen P (2002) Reading the rains: local knowledge and rainfall forecasting in Burkina Faso. Soc Nat Resour 15:409-427

Sarewitz D, Pielke RA Jr (2007) The neglected heart of science policy: reconciling supply of and demand for science. Environ Sci Policy 10:5-16

Scherer L, Verburg PH (2017) Mapping and linking supply- and demand-side measures in climate-smart agriculture. A review. Agron Sustain Dev 37:66

Scott CA, Zhang F, Mukherji A, Immerzeel W, Mustafa D, Bharati L (2019) Water in the Hindu Kush Himalaya. In: Wester P, Mishra A, Mukherji A, Shrestha AB (eds) The Hindu Kush Himalaya assessment: mountains, climate change, sustainability and people. Springer, Berlin, pp 257-299

Sharma E, Chettri N, Tse-ring K, Shrestha AB, Jing F, Mool P, Eriksson $M$ (2009) Climate change impacts and vulnerability in the Eastern Himalayas. ICIMOD, Kathmandu

Singh SP, Thadani R (2015) Complexities and controversies in Himalayan research: a call for collaboration and rigor for better data. Mt Res Dev 35(4):401-409

Smit B, Wandel J (2006) Adaptation, adaptive capacity and vulnerability. Glob Environ Change 16(3):282-292

Tewari VP, Verma RK, von Gadow K (2017) Climate change effects in the Western Himalayan ecosystems of India: evidence and strategies. For Ecosyst 4:13

Theoharides K, Barnhart G, Glick P (2009) A survey of federal and state agencies, conservation organizations and academic institutions in the United States. The association of fish and wildlife agencies, defenders of wildlife, the nature conservancy, and the national wildlife federation, Washington, DC, p 61

Tompkins EL, Adger WN (2004) Does adaptive management of natural resources enhance resilience to climate change? Ecol Soc 9(2):10

Tribbia J, Moser SC (2008) More than information: what coastal managers need to plan for climate change. Environ Sci Policy 11(4):315-328

Tse-ring K, Sharma E, Chettri N, Shrestha A (eds) (2010) Climate change vulnerability of mountain ecosystems in the Eastern Himalayas; Climate change impact and vulnerability in the Eastern Himalayas-synthesis report. ICIMOD, Kathmandu

UAPCC (2014) Uttarakhand State action plan for climate change. Government of Uttarakhand, Dehradun

UN Environment Programme (2011) Livelihood security: climate change, migration and conflict in the Sahel. UNEP, Geneva

WMO (2011) Climate knowledge for action: a global framework for climate services-empowering the most vulnerable. In: WMONo. 1065, report of the high-level taskforce towards the global framework for climate services. World Meteorological Organization (WMO), Geneva 
WMO, GFCS (2016) Climate services for supporting climate change adaptation: supplement to the technical guidelines for the national adaptation plan process. WMO-No. 1170, WMO, Switzerland

Xu J, Grumbine RE, Shrestha A, Eriksson M, Yang X, Wang YUN, Wikes A (2009) The melting Himalayas: cascading effects of climate change on water, biodiversity, and livelihoods. Conserv Biol 23(3):520-530

Ziervogel G, Bithell M, Washington R, Downing T (2005) Agent-based social simulation: a method for assessing the impact of seasonal climate forecast applications among smallholder farmers. Agric Syst 83:1-26

Publisher's Note Springer Nature remains neutral with regard to jurisdictional claims in published maps and institutional affiliations.

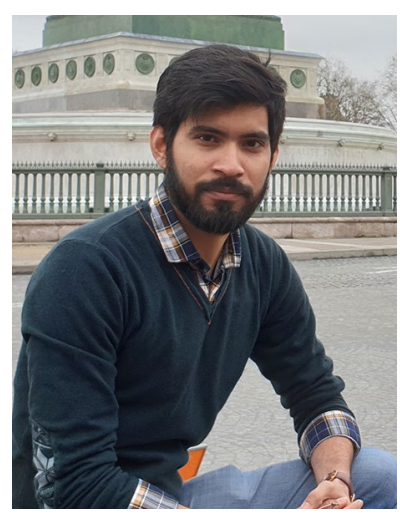

Praveen Kumar is a Ph.D. research scholar at the Spatial Analysis and Informatics Laboratory (SAIL), School of Environmental Sciences, Jawaharlal Nehru University, New Delhi. He was awarded a DAAD scholarship for a binationally supervised doctoral degree at Martin Luther University Halle-Wittenberg, Germany.

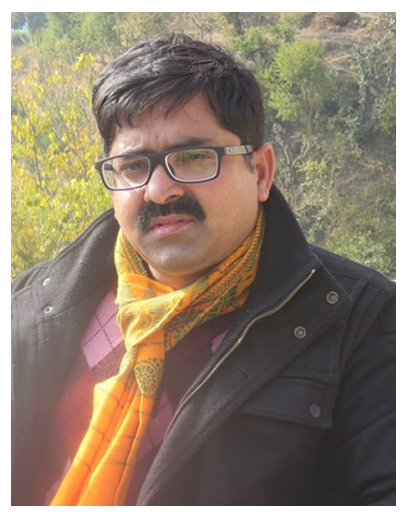

Rajiv Pandey is a senior scientist at the Indian Council of Forestry Research and Education. He is a member of the Sixth IPCC AR Team for Chapter VIII of WGII. $\mathrm{He}$ has 23 + years of research experience on forest contribution to Himalayan Communities, and vulnerability and adaptation assessment of communities.

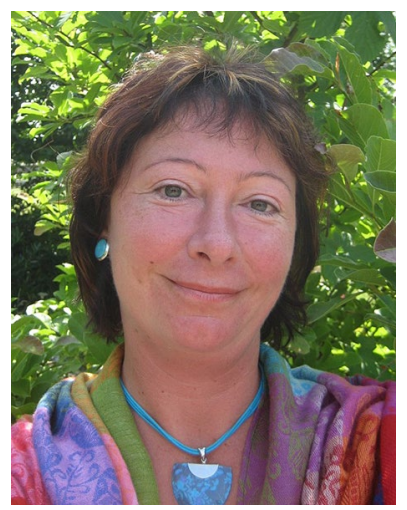

Christine Fürst is a Professor at the Department of Sustainable Landscape Development at Martin Luther University Halle-Wittenberg. Her work focuses on integrated modeling approaches for social-ecological systems, methods for environmental assessments, and evaluation of ecosystem services as well as software tools for facilitating public participation in spatial planning processes.

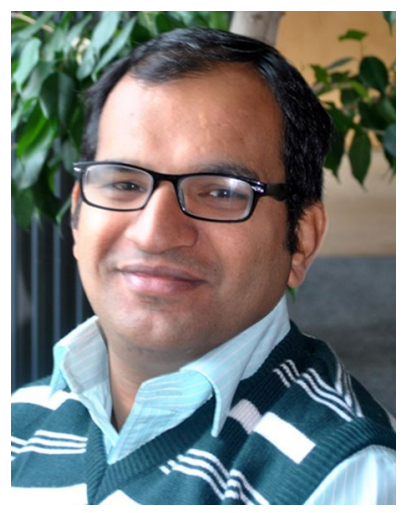

P. K. Joshi is a Professor at the School of Environmental Sciences in Jawaharlal Nehru University, New Delhi. He is trained as an environmentalist with a specialization in satellite remote sensing and GIS science. His research focuses on environmental studies including landscape characterization and climate change. 